\title{
Selection of Exhaust Scrubber: Concept for Optimal Solution
}

\section{Irina Panasiuk, Sergèjus Lebedevas, Mindaugas Česnauskis}

Klaipeda University, Klaipéda, Lithuania

Corresponding author:

I. Panasiuk, Department of Ship Engineering, Faculty of Marine Engineering, Klaipeda University, Bijūnu St 17, LT-91225, Klaipéda, Lithuania

E-mail: irina.panasiuk@gmail.com

The International Maritime Organization (IMO) through Annex VI of Marpol Convention sets $0.1 \%$ sulphur oxides $\left(\mathrm{SO}_{\mathrm{x}}\right)$ limits by 2015 in the Emission Control Area (ECA) and globally $0.5 \%$ by 2020 . These restrictions will bring not only considerable financial problems but also technical challenges for shipowners. In order to comply with the said limits and achieve the best possible economic and technological results it is very important to make a well-founded decision both for existing ships and new ships in the conceptual design phase. According to ship characteristics, the design of a scrubber system will be determined by its operating profile. There is no way to avoid extra ship operation, administration and organisation costs no matter which solution will be chosen. Therefore, the most efficient solution in the context of a particular ship is of paramount importance. The article proposes a concept to be used for $\mathrm{SO}_{\mathrm{x}}$ scrubber system selection in the conceptual design phase, by analysing technical parameters, relevant to particular ship.

Keywords: Marpol 73/78 Annex VI, ECA, SO limitation, scrubbers, low sulphur fuel.

\section{Introduction}

The global financial crisis played a significant role in the appearance of excess capacity in marine transport. As a result, this led to a sharp decline of freight prices to unacceptably low levels. Banks have reduced funding and increased interest rates in consequence of increased risk of bankruptcy of shipping companies. In addition to the rather complicated financial situation in the world market, international regulations will soon come into force.

The IMO through Annex VI of MARPOL sets limits on $\mathrm{SO}_{\mathrm{x}}$ emissions from ship exhausts: the content of $\mathrm{SO}_{\mathrm{x}}$ in marine fuel should be reduced to $0.1 \%$ by 2015 in the ECA and globally to $0.5 \%$ in 2020 (MARPOL 73/78, 2008). In the medium and long term it can be expected that most of global trading centres will pass through ECA zones. These restrictions will bring not only considerable financial problems, but also technical challenges for ship owners. The regulations are applicable not only to new buildings but also to existing fleet. That is why this research was done in order to propose the methodology for suitable solution, in particular with respect to existing ships, sailing primarily in ECAs.

The most straightforward method of reducing $\mathrm{SO}_{\mathrm{x}}$ emissions is to simply reduce fuel sulphur content. Nevertheless, this solution still requires that it be feasible for the refineries to lower the sulphur level at a reasonable cost and effort (Schinas et al., 2014).

The alternative to low sulphur fuel is the aftertreatment of exhausts (scrubbing). Exhaust gas scrubbing is a common and proven technology on land. However, the conditions on ships differ significantly, and there are some limiting factors, which will be discussed in the article.

\section{Methods}

\subsection{The scrubber system: type selection}

A scrubber is a device installed in the exhaust system after the engine or boiler that treats the 
exhaust gas with a variety of substances including sea water, chemically treated fresh water or dry substances, so as to remove most of the $\mathrm{SO}_{\mathrm{x}}$ from the exhaust. There are two types of scrubbers: wet and dry. The dry scrubber uses dry chemicals, and the wet scrubber uses water as a scrubbing medium. Wet scrubbers are more acceptable for ships because of their lower price and smaller dimensions of units. That is why the wet type of scrubber is the most widely used in shipbuilding. There are three main types of wet scrubbers: the open loop, which uses only sea water; the close loop, which uses fresh water mixed with caustic soda; the hybrid, which has both benefits of the open and the closed loop (ABS, 2013; DNV, 2012; Holmgren et al., 2014; Kalli et al., 2009).

Regardless of the type, wet scrubbers are normally placed high up around the exhaust funnel. There is more available space, and access is easier. In such arrangement the scrubber can be operated without the scrubbing process using a bypass mode or run dry without the scrubbing process, when exhaust gas cleaning is unrequired. Furthermore, the scrubber is an efficient noise abatement device on board ships, and it can replace an existing silencer (Lloyd's Register, 2012).

The open loop scrubber installation is relatively simple. The system supplies sea water directly to the scrubber. After scrubbing the used water is discharged to the sea. The system has low operating costs as no additional water treatment is required. However, sea water flow rate is relatively high. Combined with the required pressure for the highly placed scrubber, the power needed for scrubbing is a running cost that cannot be ignored. In certain cases, in areas where the seawater alkalinity is too low or restricted outlet criteria are in force, the system cannot be used, and running on low sulphur fuel is required.

The closed loop scrubber installation is more complex compared to that of the open loop because a water treatment system is needed. The equipment includes caustic soda, circulation and sludge tanks, pumping and fresh water cooling systems and a waste control unit. An alternative to the waste control unit could be a holding tank to store the bleed-off water for discharge in port. Compared to open loop systems, the scrubber water flow is significantly reduced as the scrubbing efficiency using the close loop is high compared to open loop. Due to reduced flow, the dimensions of inlet and outlet pipes are reduced. The running cost of the closed loop system is higher compared to the open loop system, mainly because of the addition of chemicals in the process. However, the closed system can be used in any area without any restrictions.

The scrubber water installation in the hybrid system is a combination of the system used in open loop and closed loop installations. The hybrid system combines the low running costs of the open loop with the flexibility provided by the closed loop system. The hybrid system provides additional flexibility, as the open loop mode can be used also at low SW alkalinity with the addition of $\mathrm{NaOH}$ without the need for switching to closed loop mode (MAN, 2014).
Further the elements of the proposed methodology relevant to scrubber's conceptual design phase will be discussed. The working principle is almost the same for scrubbers of different equipment manufacturers. It means that scrubbers are approximately the same in size and mass, in pumping capacities, caustic soda solution, etc. That is why differences between manufacturers are not taken into account. Because of the possibility to use close loop scrubbers almost universally, the article focuses on the mentioned system.

The scrubber location depending on the configuration

The scrubber unit should always be installed in vertical direction. Horizontal positioning is not possible as the efficient exhaust gas cleaning requires countercurrent interaction between the exhaust gas and scrubbing water. As a default the scrubber system is designed for maximum engine load and fuel sulphur content up to $3.5 \%$. The $\mathrm{SO}_{\mathrm{x}}$ reduction efficiency is $97.15 \%$, corresponding to a reduction of fuel sulphur content from $3.5 \%$ to $0.1 \%$. In practice scrubber systems are available in two different configurations: single or multi stream.

A single stream scrubber is designed to be installed in the main exhaust gas stream of an individual diesel engine. This means separate scrubbers for each exhaust stream. The solution is advantageous for single main engines, with generator engines and oil-fired boilers using low sulphur fuel. Single stream scrubbers are usually located in the engine casing or funnel in the direction of flow after the silencer. Gas inlet is radial from side, and outlet is vertical from the top. Cleaned exhaust gases are passing through a droplet separator before entering the stack. The scrubber unit is equipped with a wet sump to eliminate the need for a separate process tank. A wet sump minimises the needed vertical lifting height and therefore the power demand of the circulation pumps.

If there is a need to clean not only the exhaust gas of the main engine, using of the multi-stream system is recommended. A multi-stream scrubber is designed to clean the exhaust gases of several main and auxiliary engines and oil-fired boilers on board with one scrubber unit. Another benefit is that it does not increase the exhaust gas back pressure, making it particularly suitable for oil fired boilers. An ideal location for a multi-stream scrubber, serving several combustion units, is aft of or within funnel enclosure. This arrangement gives a minimum loss of useable cargo or accommodation space with functional gas flow and access to main components. The rest of the exhaust systems and casing are following conventional design with silencers installed before the scrubber intake. Operation is similar to that of a single stream scrubber, but with certain consideration to machinery operational profile. In order to measure the dimension of a multi-stream scrubber system properly, it is relevant to identify the maximum propulsion (full speed) and electrical power as well as 
heat demand of the ship. In the case of a multi-stream scrubber, the maximum exhaust gas flow is designed to cover all relevant operating modes.

\section{Results and discussion}

\subsection{The closed loop scrubber system selection: space required in the exhaust funnel}

The volume required to install the scrubber in the exhaust funnel can be determined as dependence between the power of combustion units and the capacity of the scrubber. The capacity of scrubbers, in turn, directly depends on the exhaust gas flow. Accordingly, there is a need to calculate overall exhaust gas flow from all combustion units. If it is a single stream, there is a need to calculate the power of combustion unit separately. In the case of the multistream system, we should take into account the overall power of combustion units. The higher the exhaust gas flow from combustion units, the more powerful scrubber is required. The scrubber is designed for continuous operation at full specified gas flow (ISO 8178-1, 2006, Mollenhauer et al., 2010). Also, there are significant differences between parameters of 2-stroke and 4-stroke engines, influencing the selection of a scrubber. A 4-stroke engine has higher exhaust temperatures than a 2stroke engine, which means that for the same volumetric flow of exhaust, more water is required for cooling and saturation. A 2-stroke engine has higher volumetric flow of exhaust than a 4-stroke engine, which means that for the same power of engines volumetric flow of exhaust more power of scrubber is required. Depending on the characteristics of combustion units, the maximum exhaust gas flow can be calculated using the following equation:

$$
G_{\text {gas }}=G_{\text {fuel }} \times L_{0} \times \alpha \times \varphi
$$

where $G_{\text {gas }}$ is the maximum exhaust gas flow $(\mathrm{kg} / \mathrm{h})$, $G_{f u e l}$ is gas and nominal fuel consumption, $G_{f u e l}=P_{\text {emax }} \times b_{\text {emax }} \mathrm{kg} / \mathrm{h}, L_{0}$ is stoichiometric air-fuel constant (accepted $14.5 \mathrm{~kg}$ air $/ \mathrm{kg}$ fuel), $\alpha$ is real coefficient of air excess, $\varphi$ is air mass flow ratio (accepted 1.45 for a 2-stroke and 1.1 for a 4-stroke engine) (Mollenhauer et al., 2010).

The differences between a 2-stroke engine and a 4-stroke engine in equation 1 are determined by the air mass flow ratio. The exhaust gas flow per combustion unit power is the main parameter when choosing the required capacity of a scrubber for a particular ship (Fig. 1). The dimensions of the scrubber unit mainly depend on the exhaust gas mass flow. In accordance with the above calculations, the dependence of scrubber's weight and volume per its capacity has the following form (Fig. 2).

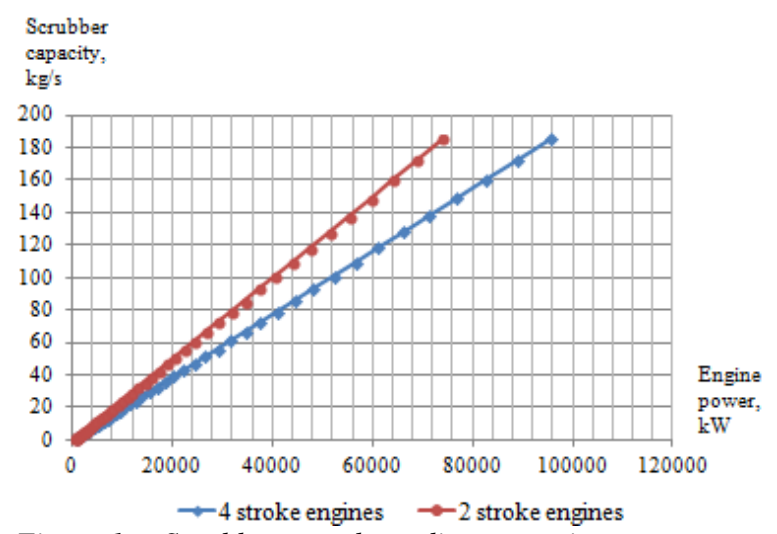

Figure 1. Scrubber type depending on engine power.

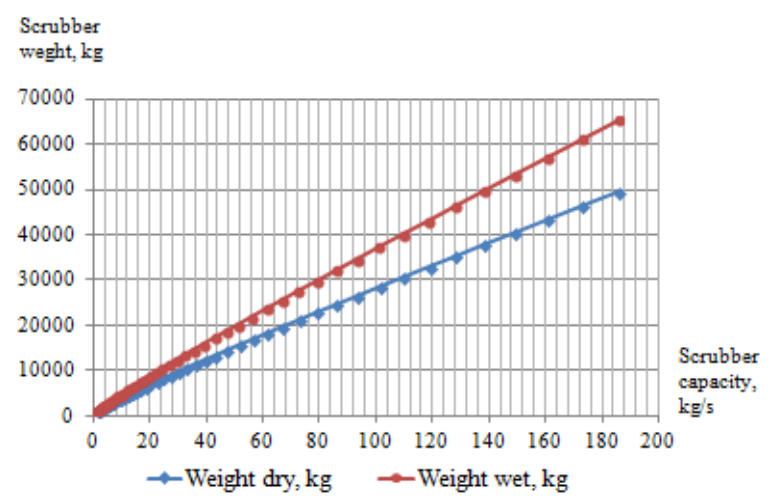

Figure 2. Scrubber weight per scrubber capacity.

The space required in the exhaust funnel can be calculated as a dependence of scrubber volume per scrubber capacity (Fig. 3).

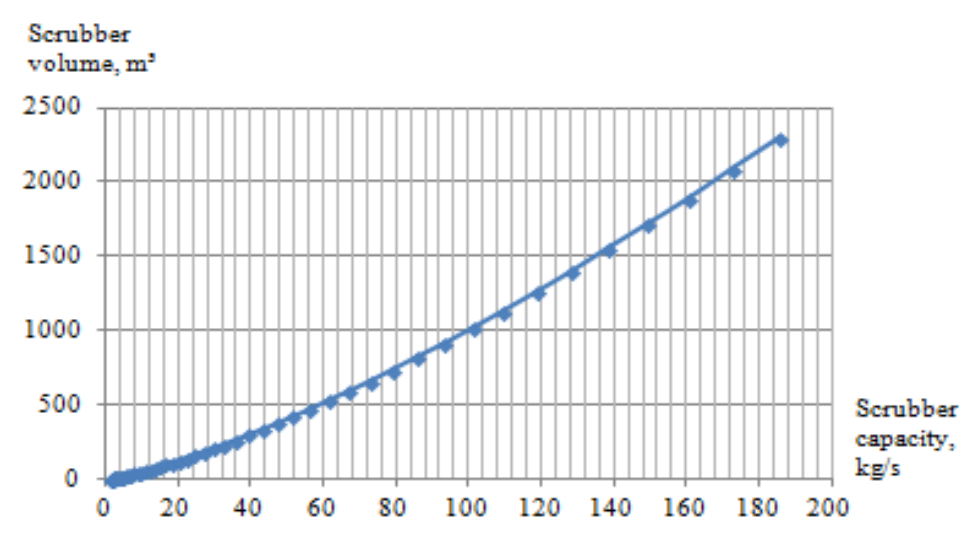

Figure 3. Scrubber volume per scrubber capacity. 
The scrubber unit weight is affected by the selection of materials. As a standard concept, the scrubber unit is made of suitable corrosion-resistant metals. Scrubber units made of glass-reinforced plastic (GRP) are lighter and therefore suitable for mounting high up in stability sensitive ships. Weight saving compared to a metallic scrubber unit is 20-30\% (Wärtsilä, 2013a, MAN Diesel and Turbo, 2013). It is very important to design the scrubber system with minimum weight, due to its high vertical centre of gravity.

\subsection{The closed loop scrubber system selection: space required in the engine room}

In the case of a closed loop scrubber, the space required in the engine room can be determined as a sum of overall volume of tanks, pipes, pumps, and water treatment systems. The exact size of various elements of scrubber system can only be determined when the system has been designed. However, on the conceptual phase of selection of the scrubber system we can state that each element depends on exhaust gas flow or, in other words, on scrubber capacity. The length of the pipes depends on the horizontal and vertical distance between the scrubber's place of installation and the sea chest. All of the components should be placed as near to each other as possible in order to reduce additional weight caused by piping, and to reduce the work of installation (Walter et al., 2012).

The closed loop scrubbing water is circulated through the system. Only small bleed-off is extracted from the loop, and fresh water and alkali are added. The flow rate of scrubbing water is related to actual dimensions of the scrubber unit and the total water balance. Scrubbing water is circulated in two circuits. In the first circuit scrubbing water is circulated from wet sump to spray nozzles below the packing bed inside the scrubber unit. In the second circuit scrubbing water is circulated from the wet sump to the cooling heat exchanger to reduce the scrubbing water temperature. From the heat exchanger the scrubbing water is routed to spray nozzles on top of the packing bed. Typically the module consists of two identical pumps. Ideal location is below the wet sump of the scrubber unit to minimise piping and vertical lifting height. The capacity of scrubbing water pumps is 13$20 \mathrm{~m}^{3} / \mathrm{MWh}$ per pump.

To remove the accumulated impurities from the scrubbing water a small flow (bleed-off) is extracted from the circulation. The bleed-off treatment unit is a complete system designed for cleaning bleed-off from the fresh water scrubber. Clean effluent from the treatment unit is discharged overboard or led to the buffer for a scheduled and periodical discharge. Typically there are two bleed-off units; one of them is a stand-by unit. As a rule the bleed-off can be estimated to be 50 litres/MWh per fuel $\mathrm{S} \%$. The bleed-off system weight in operating is approximately $1,800 \mathrm{~kg}$ and volume $4.5 \mathrm{~m}^{3}$ (Wärtsilä, 2013b).

Fresh water is needed to compensate scrubbing water evaporation losses and extracted bleed-off.
Fresh water supply is normally connected to the scrubbing water pump module. As a rule the fresh water consumption can be estimated to be 50 litres/MWh per fuel S\%. However, the consumption can differ from this on project specific basis. The capacity of the fresh water pump unit should be dimensioned based on the maximum fresh water consumption with clear margin.

Exhaust gas heat is transferred to scrubbing water and removed in the seawater heat exchanger. The purpose of the cooling is to minimise water content in the cleaned exhaust gas after the scrubber, thereby minimising plume opacity and fresh water consumption. The cooling has no effect on sulphur removal efficiency from exhaust gases. Typically there is a need of one heat exchanger per scrubber with capacity $15-22 \mathrm{~m}^{3} / \mathrm{MWh}$.

Alkali is automatically added to the scrubbing water circulation to maintain the process $\mathrm{pH}$ and consequently the $\mathrm{SO}_{\mathrm{x}}$ removal efficiency. Typically $50 \% \mathrm{NaOH}$ solution is used as alkali. Alkali consumption depends on the concentration of the solution, engine operating power, engine specific fuel oil consumption and fuel sulphur content. As a rule the alkali consumption can be estimated to be 5 litres/MWh per fuel sulphur content $(\%)$ for $50 \%$ $\mathrm{NaOH}$ solution.

Alkali feed module consists typically of two pumps. In normal operating conditions one pump is in operation and the other pump is used as a stand-by. To minimise the length of the suction line the preferred location of the alkali feed module is near the storage tank. Typically there is a need of one module per scrubber with weight in operating condition of $200-300 \mathrm{~kg}$ and volume $0.5-1.0 \mathrm{~m}^{3}$.

The alkali transfer pump is used for pumping the alkali from the storage tank to fill small tanks in bleed-off treatment units. The bleed-off treatment unit uses the alkali in the treatment process. The alkali transfer pump capacity could be, for example, 10$15 \mathrm{~m}^{3} / \mathrm{h}$, depending on the size of the alkali tank and required time for emptying the tank.

Sludge generated in the scrubber process is similar to engine room sludge. The sludge consists mainly of hydrocarbons, soot and metals. The amount of water is minimised in the treatment unit, still keeping it pumpable. The amount of generated sludge is approximately $0.1-0.4 \mathrm{~kg} / \mathrm{MWh}$. The scrubber sludge can be stored in the same tank as other engine room sludge. The scrubber sludge is not permitted to be incinerated on board.

The required capacity of a storage tank can be calculated by comparing it to the fuel consumption. If ship's annual fuel consumption is 10,000 tonnes and the average fuel sulphur content is $2.5 \%$, the corresponding alkali consumption is $630 \mathrm{~m}^{3}$ per year. If alkali is bunkered every two weeks the required amount is $24 \mathrm{~m}^{3}$. For vessels that are operating in regular routes or in specific areas, the storage capacity could be equal to the fuel bunkering interval. The ideal storage capacity should be at least 1.5 times the volume of the truck. It is recommended that two separate, preferably adjacent, structural tanks be 
provided for alkali. This configuration would allow continuous scrubber operation during the tank surveys, inspections and cleaning (Wärtsilä, 2013a).

$\mathrm{SO}_{\mathrm{x}}$ emission monitoring is connected to the scrubber control system to provide data logging and reporting. The weight and dimensions of the system are approximately $350 \mathrm{~kg}$ and $1.0 \mathrm{~m}^{3}$.

A single stream scrubber is typically placed in the engine casing after the silencer. Cleaned exhaust gases leave the scrubber vertically from top of the scrubber. Before the scrubber unit a by-pass damper is arranged to suction branch connected to the scrubber. In the multi-stream system all the exhaust gas pipes are collected in a common manifold, which is connected to the scrubber unit. Before the manifold by-pass dampers are arranged to each suction branch connected to the scrubber. Traditional exhaust pipes remain as by-pass pipes. During normal operation the by-pass pipes are closed, preventing any escape of uncleaned gases. When the scrubber is not in operation, the by-pass pipes permit by-passing of the scrubber.

In the multi-stream scrubber concept, a frequency controlled exhaust gas fan is used to suck the cleaned exhaust gases from the scrubber unit. The fan rotation speed is controlled based on the measurement of pressure difference over the by-pass flap in the bypass damper. The fan keeps small under pressure at the bypass flap exhaust gas side ensuring that the possible leakages are always inwards. For each installation the fan configuration depends on scrubber capacity.

The power demand of the scrubber in normal conditions varies between 0.4 and $0.6 \%$ of the prevailing engine power. The power consumption is lower in colder sea water temperatures than in tropical conditions. The power demand of the multi-stream scrubber increases towards top ship speeds to around maximum of $1 \%$.

All mentioned aspects should be taken into account when designing the scrubber system for a particular ship. As well as fulfilling the technical conditions required to install the scrubber system, there is a need to check the influence on ship's operations. As the scrubber is massive and heavy, it greatly affects the load capacity, ship stability and strength, which will be analysed in further investigations.

\section{Conclusions}

The described concept of scrubber system selection allows to state that the configuration of the scrubber system directly depends on the combustion unit power. It means there is direct dependence between engine or boiler power and the capacity of each element of the scrubber system. This dependence allows evaluating overall system space and mass requirements when only combustion power is known.

The scrubber system has a significant influence on ship's load capacity, stability and strength. That is why the solution to comply with $\mathrm{SO}_{\mathrm{x}}$ emission limits should be based also on assessment of ship's technical characteristics. The mentioned assessment will be analysed in further investigations.

\section{References}

ABS (2013). Exhaust Gas Scrubber Systems: Status and Guidance. Available at: http://www.eagle.org/ eagleExternalPortalWEB/ShowProperty/BEA\%20Repo sitory/References/Capability\%20Brochures/ExhaustScr ubbers (accessed 22/05/2014).

DNV (2012). Shipping 2020. Available at: http://www.dnv.nl/binaries/shipping\%202020\%20\%20final\%20report_tcm141-530559.pdf (accessed 22/05/2014).

Holmgren, J., Nikopoulou, Z., Ramstendt, L., Waxenius, J. (2014) Modelling modal choice effects of regulation on low-sulphur marine fuels in Northern Europe. Transport and environment 28: 62-73. doi: http://dx.doi.org/ $10.1016 /$ j.trd.2013.12.009.

ISO 8178-1 (2006). Reciprocating internal combustion engines. Available at: http://www.iso.org/iso/ catalogue_detail.htm?csnumber $=42714 \quad$ (accessed 25/05/2014).

Kalli, J., Kavinen, T., Makkonen, T. (2009). Sulphur content in ships bunker fuel in 2015. A study on the impacts of the new IMO regulations on transportation costs. The ministry of transport and communications of Finland. Helsinki, pp. 38. Available at: http://www.lvm.fi/docs/en/339549_DLFE-8042.pdf (accessed 6/05/2014).

Lloyd's register (2012). Understanding exhaust gas treatment systems. Available at: http://www.lr.org/en/_images/12-

9890_ECGSguide1212_web_tcm155-240772.pdf (accessed 15/05/2014).

MAN Diesel and Turbo (2013). Emission project guide. Available at: http://www.mandieselturbo.com/ download/project_guides_tier2/printed/7020-0145001web.pdf (accessed 25/05/2014).

MARPOL 73/78 (2008). Regulation for the prevention of air pollution from ship. Revised Annex VI to International Convention MARPOL 73/78, IMO. London.

Mollenhouer, K., Tschoke, H. (Eds.) (2010). Handbook of diesel engines (p. 636). Germany: Springer (ISBN 9783-540-89083-6). doi: http://dx.doi.org/10.1007/978-3540-89083-6.

Schinas, O., Stefankos, C. (2014) Selecting technologies towards compliance with MARPOL Annex VI: The perspective of operators. Transport and environment 28: 28-40. doi: http://dx.doi.org/10.1016/j.trd.2013.12.006.

Walter, J., Wagner, J. (2012) Choosing exhaust scrubber systems. Maritimes Cluster Northern Germany. Available at: http://www.maritimes-cluster.de/ fileadmin/user_upload/MC/PDF/2013-02-

27_Studie_Abgasw\%C3\%A4schersysteme_final_englis ch.pdf (accessed 25/05/2014).

WARTSILA (2013). Product guide. Finland. p. 208.

WARTSILA (2013). Wärtsilä marine scrubber references. Public report. Finland. p. 46. 


\title{
Išmetamụjų dujų skruberio pasirinkimas: optimalaus sprendimo koncepcija
}

\author{
Irina Panasiuk, Sergejjus Lebedevas, Mindaugas Česnauskis
}

Klaipédos universitetas, Klaipéda, Lietuva

\begin{abstract}
Tarptautinès jūrų organizacijos Marpol konvencijos VI priede leistina laivų išmetamųjų dujų $\mathrm{SO}_{\mathrm{x}}$ koncentracija išmetamujų teršalų kontrolès rajonuose (ECA) sumažinta iki $0,1 \% 2015$ m., o globaliai - iki $0,5 \% 2020$ m. Šie reikalavimai lems ne tik laivu eksploatavimo finansinius rodiklius, bet ir taps rimtu technologiniu išbandymu laivų savininkams. Efektyviausio išmetamuju dujų valymo metodo pasirinkimas eskizinio projektavimo etape yra gyvybiškai svarbus kiekvienai laivybos įmonei. Priklausomai nuo laivo charakteristikos, skruberio pasirinkimą lems ir laivo eksploatavimo sąlygos. Nepriklausomai nuo to, kokį metodą pasirinks laivų savininkai, papildomu kapitalo ir eksploatacijos sąnaudų išvengti nepavyks. Tačiau atsižvelgiant ì konkretų atvejį, įmanoma ir būtina parinkti optimalų sprendimą, kuriuo būtų užtikrintos mažiausios papildomos sąnaudos. Straipsnyje pateikiama skruberio parinkimo koncepcija, leidžianti, atsižvelgiant ị laivo charakteristiką, nustatyti reikiamus skruberio techninius parametrus.

Raktiniai žodžiai: Marpol konvencija 73/78 VI priedas, ECA, SO $O_{x}$ ribojimas, skruberiai, mažasieris kuras.
\end{abstract}

